\title{
Design of PBL-Based Differential Calculus Module to Stimulate Students' Critical Thinking Skills
}

\author{
Kurnia Fermani Hidayah ${ }^{1}$, Suparman ${ }^{1, *}$, Yahya Hairun ${ }^{2}$, Diah Prawitha Sari ${ }^{2}$ \\ ${ }^{1}$ Department of Mathematics Education, Faculty of Teacher Training and Education, Ahmad Dahlan University, Indonesia \\ ${ }^{2}$ Department of Mathematics Education, Faculty of Teacher Training and Education, Khairun University, Indonesia
}

Received February 13, 2020; Revised March 17, 2020; Accepted March 28, 2020

Copyright $\odot 2020$ by authors, all rights reserved. Authors agree that this article remains permanently open access under the terms of the Creative Commons Attribution License 4.0 International License

\begin{abstract}
Critical thinking is a skill that must be possessed by students in the 21 st century and the industrial revolution 4.0 era. The Problem Based Learning (PBL) model can be used by teachers to improve students' critical thinking skills. However, teachers need appropriate learning resources to develop students' critical thinking skills. This research aims to design learning resources that are compatible with PBL models which can stimulate students' critical thinking skills. This type of research uses ADDIE. Research instruments use observation guidelines, interview guidelines, and validation guidelines. This research is resulted in the design of learning modules that are compatible with PBL models. The results of the validation from media experts indicate that the module design is very good. This design can be used as a reference in developing modules. This research can be continued at the module development stage to produce modules that fit the PBL model and can stimulate students' critical thinking skills.
\end{abstract}

Keywords Critical Thinking Skills, Differential Calculus Module, Problem Based Learning

\section{Introduction}

Critical thinking skills are important basic competencies. This skill is not only to fulfill the demands of learning mathematics but also to an awareness of the importance of mathematics in life. Critical thinking skills are considered so important that needs to be taught and included in learning in schools $[1,2]$. Critical thinking skills are skills needed in the 21 st century [3]. The characteristics possessed by mathematics can lead to learning mathematics to build students' critical thinking skills [4].

Critical thinking is an active learning process for agreeing or disagreeing with information, judging to determine the truth, and changing misinformation to create new ideas [5]. Critical thinking skills of students need to be trained using contextual problems in everyday life [6]. The purpose of planting critical thinking is that students are not as recipients of information, but as users of information. This is because the learning environment that actively involves students in the investigation of information and the application of knowledge will improve critical thinking skills [7].

There are seven stages in critical thinking, namely (1) identifying facts, (2) connecting with other relevant knowledge, (3) formulating the problem, (4) considering all possible solutions, (5) determining the possibility of resolution, (6) comparing patterns, differences and similarities from various sources of evidence, (7) making conclusions [8].

Learning models that can improve critical thinking skills are problem-based learning models [4, 9-13]. Problem Based Learning (PBL) model is one of the learning models based on unstructured problems, open problems, problems that do not have definite answers [14]. The problem-based learning model is student-centered and has advantages that can make learning useful for the real world and motivate students to develop their skills. [15, 16]. Through PBL, students learn in groups, become partners in the teaching and learning process, can handle new situations, and develop life-long skills [15].

Stages in Problem Based Learning are (1) the orientation of students to the problem, (2) organizing students to learn, (3). assisting individuals and group investigations, (4) developing and presenting the work, (5) analyzing and evaluating the problem-solving process [17].

Good teaching materials are systematically compiled material that supports students to learn [18]. Teaching material is a type of material to assist teachers in conducting teaching and learning activities in class so as to increase student interest [19]. Textbooks are teaching 
material that tends to be the main guide for teachers and students to learn. Teaching materials become a very important role but have not been supported by the provision of adequate teaching materials in accordance with the characteristics of students [20]. The problems presented in most books are not related to the mathematical context of everyday life, so learning mathematics becomes far from students' lives [21].

However, the learning resources used today are modules that have several shortcomings. These deficiencies are (1) The module has not motivated students to improve their students' critical thinking skills, (2) The module has not used an appropriate learning model to stimulate critical thinking skills (3) This module has not motivated students to ask questions and explore information. Based on the above, researchers are interested in conducting research related to the development of learning modules with the Problem-based Learning model. This research is entitled "Design of PBL-Based Differential Calculus Module to Stimulate Students' Critical Thinking Skills".

\section{Materials and Methods}

The type of research used is Research and Development (R\&D). The development model used is ADDIE. This ADDIE model stands for five stages, Analysis, Design, Development, Implementation, and Evaluation [22]. Development of module is designed to stimulate critical thinking skills that match the problem-based learning model using ADDIE [23-25]. The stages of the ADDIE model are presented in Figure 1.

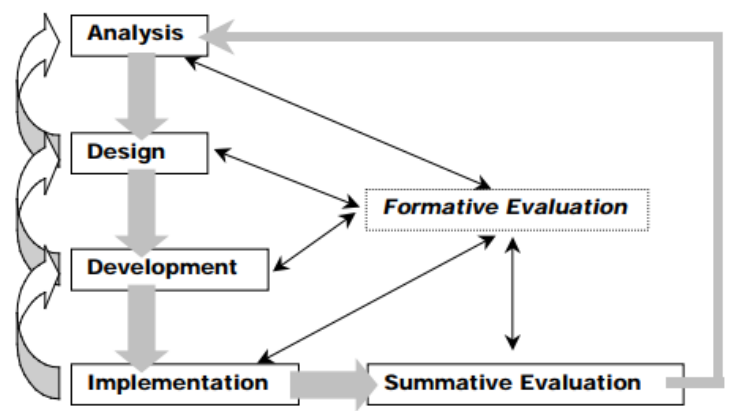

Figure 1. ADDIE Stages [26]

The subjects in this research were students of $\mathrm{Abu}$ Bakar Yogyakarta Integrated Islamic High School. The research instruments used included observation guidelines, interview guidelines, and validation guidelines. Observation guidelines are used to find out the curriculum used. Interview guidelines are used to determine students' responses in understanding material and material that is considered difficult. Validation guidelines are used to validate the design of modules that are developed. Validation is carried out by media experts. The data analysis technique used is descriptive analysis
This research is limited in two stages, namely the analysis stage and the design stage. The analysis stage in this research is curriculum analysis and analysis of students' needs for the use of learning modules that are appropriate to the character of students. The results of the analysis are used as a basis for developing mathematics learning modules. The design stage carried out in this research is to design the initial form of the module to be developed.

\section{Result and Discussion}

This research designed a mathematics learning module design that was appropriate to the PBL model to stimulate critical thinking skills. The results of the development of the module design at the ADDIE Analysis and design stage are as follows.

\subsection{Analysis Stage}

This analysis is a learning plan conducted to find out material that is considered difficult by students. Based on interviews conducted by researchers with students and mathematics teachers at Abu Bakar Yogyakarta Integrated Islamic High School, the material considered difficult by students and presented in the module is Calculus on the derivative of functions. Based on the results of observations, it is known that the curriculum used is the 2013 curriculum. From the results of observations, it is also known that students' discussion and student activity in mathematics learning is still lacking. Students rely on the teacher as a learning center so that student learning activities tend to be passive.

The basic competencies to be achieved for differential learning based on the 2013 curriculum are shown in Table 1 .

Table 1. Basic Competencies

\begin{tabular}{|c|l|}
\hline No & Basic Competencies \\
\hline 3.9 & $\begin{array}{l}\text { Analyze the relationship of the first derivative of the function } \\
\text { with the maximum value, minimum value, and the interval of } \\
\text { the function monotony and the tangent curve of the curve. }\end{array}$ \\
\hline 4.9 & $\begin{array}{l}\text { Use the first derivative of a function to determine the } \\
\text { maximum point, minimum point, and the monotonic interval } \\
\text { of the function, as well as the slope of the tangent curve, } \\
\text { tangent equation, and the normal line of the curve associated } \\
\text { with contextual problems. }\end{array}$ \\
\hline
\end{tabular}

Students need modules that can stimulate critical thinking skills that are appropriate to the problem-based learning model on functional derivative material.

\subsection{Design Stage}

After analysis, the next stage is the design stage. The design stages include media selection, format selection, and initial design. Designs created include: 


\subsubsection{Cover}

Cover for Module Design consists of front cover and back cover. The front cover contains the title of the Module, which is "The Math Module for Using Differential Calculus," as in Figure 2 and the back cover contains the Author Biography as in Figure 3.

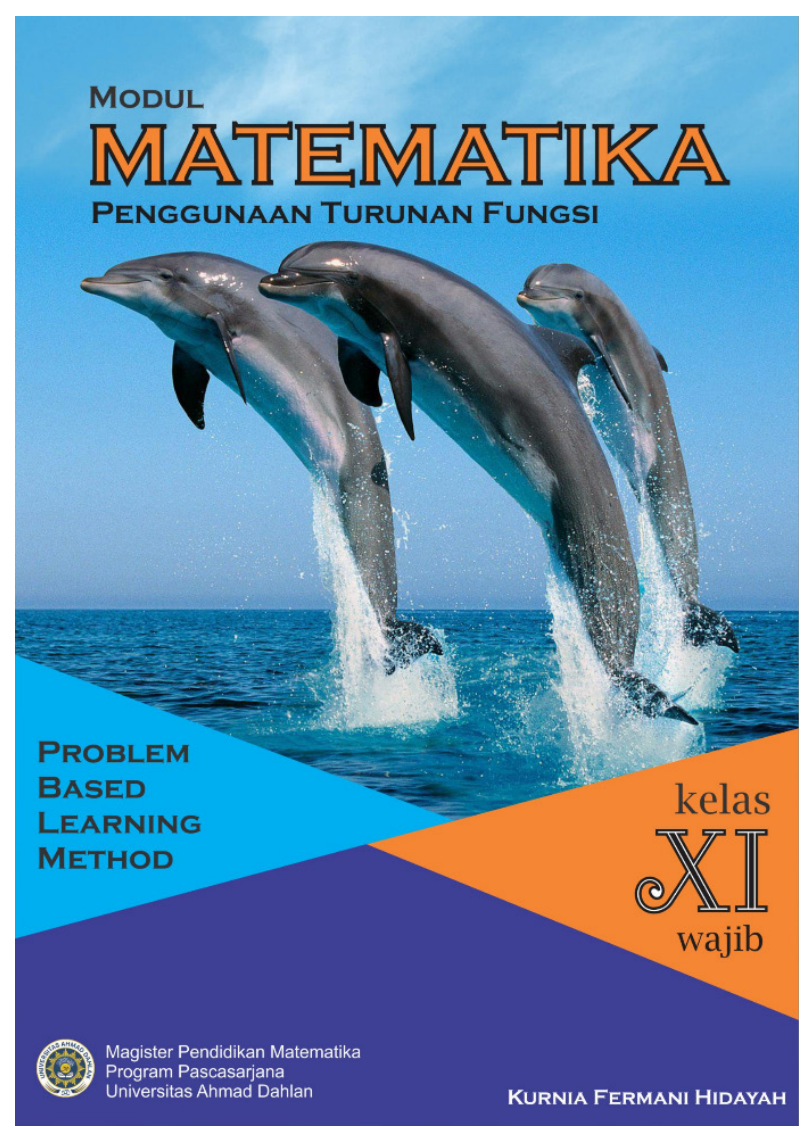

Figure 2. Front Cover Module

The front cover of the module, in addition to containing the title of the module, also contains the class level, namely class XI for compulsory mathematics subjects. Besides that, the cover is also written about the learning method used in the module content, the Problem Based Learning method.
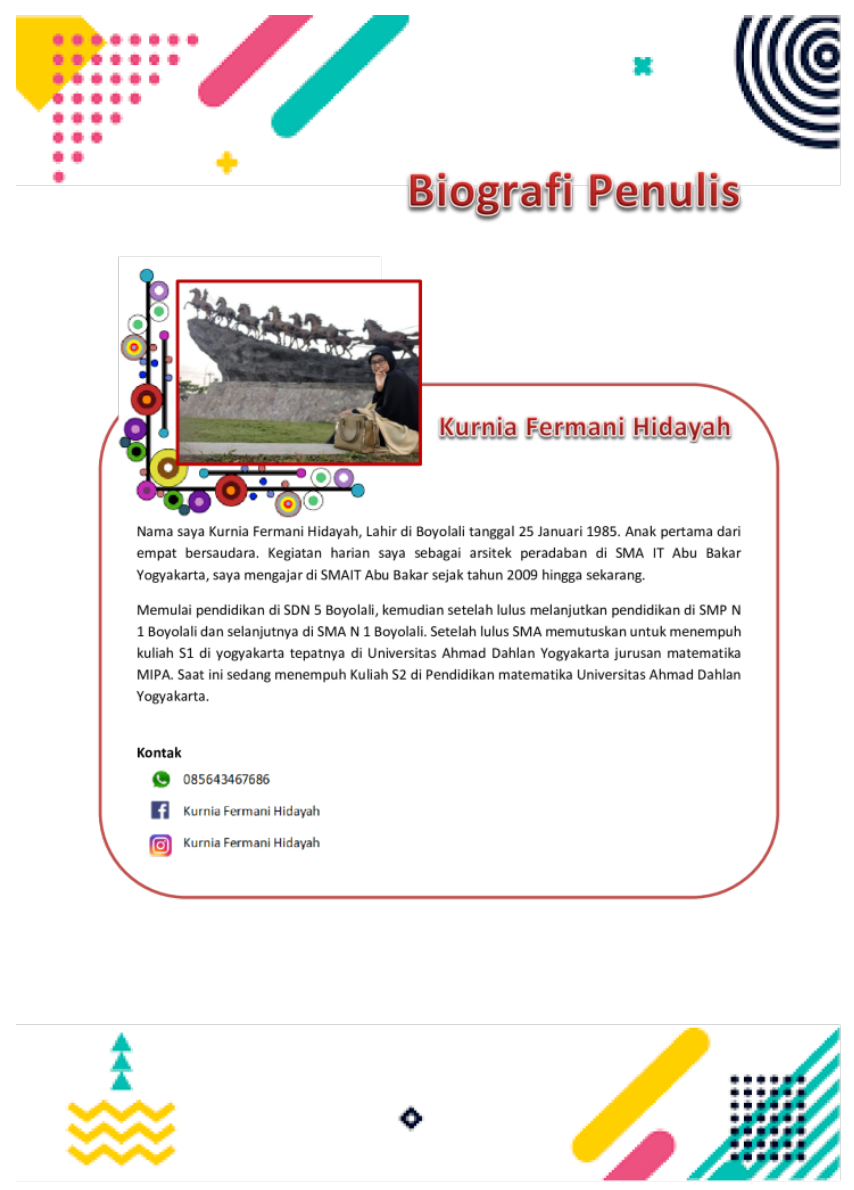

Figure 3. Author Biography

In figure 3, the Author Biography contains the author's name, place, and date of birth, educational history, and contact details.

\subsubsection{Introduction}

Introduction functions to deliver the reader or module user to the content contained in it. The introduction contains thanks to all those who have helped the author in completing the module and apologies if there are deficiencies in the module. An introduction can be seen in Figure 4 


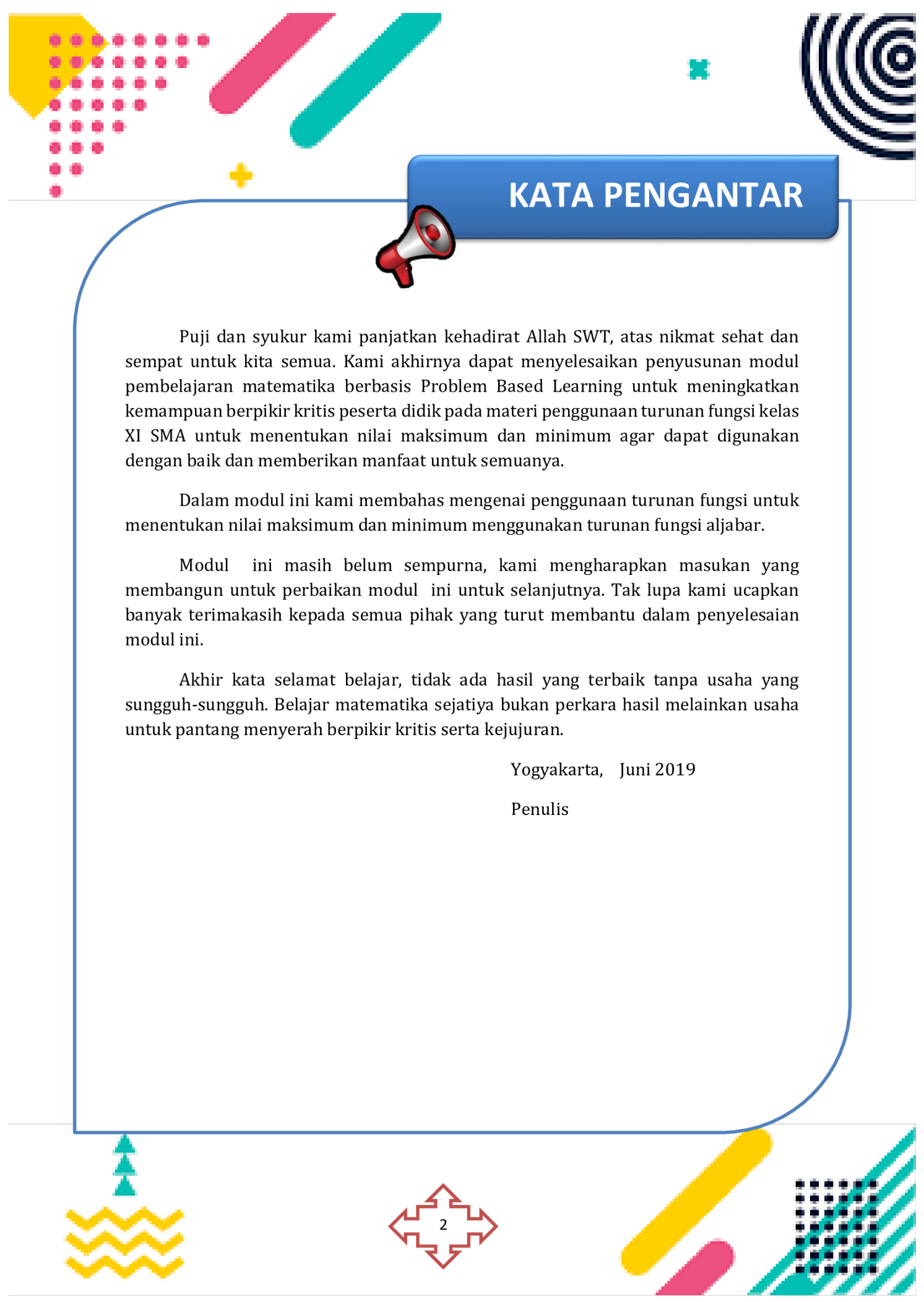

Figure 4. Introduction 


\subsubsection{Table of Contents}

Table of contents is used to outline what content is contained in the Module. Design the list as shown in Figure 5.
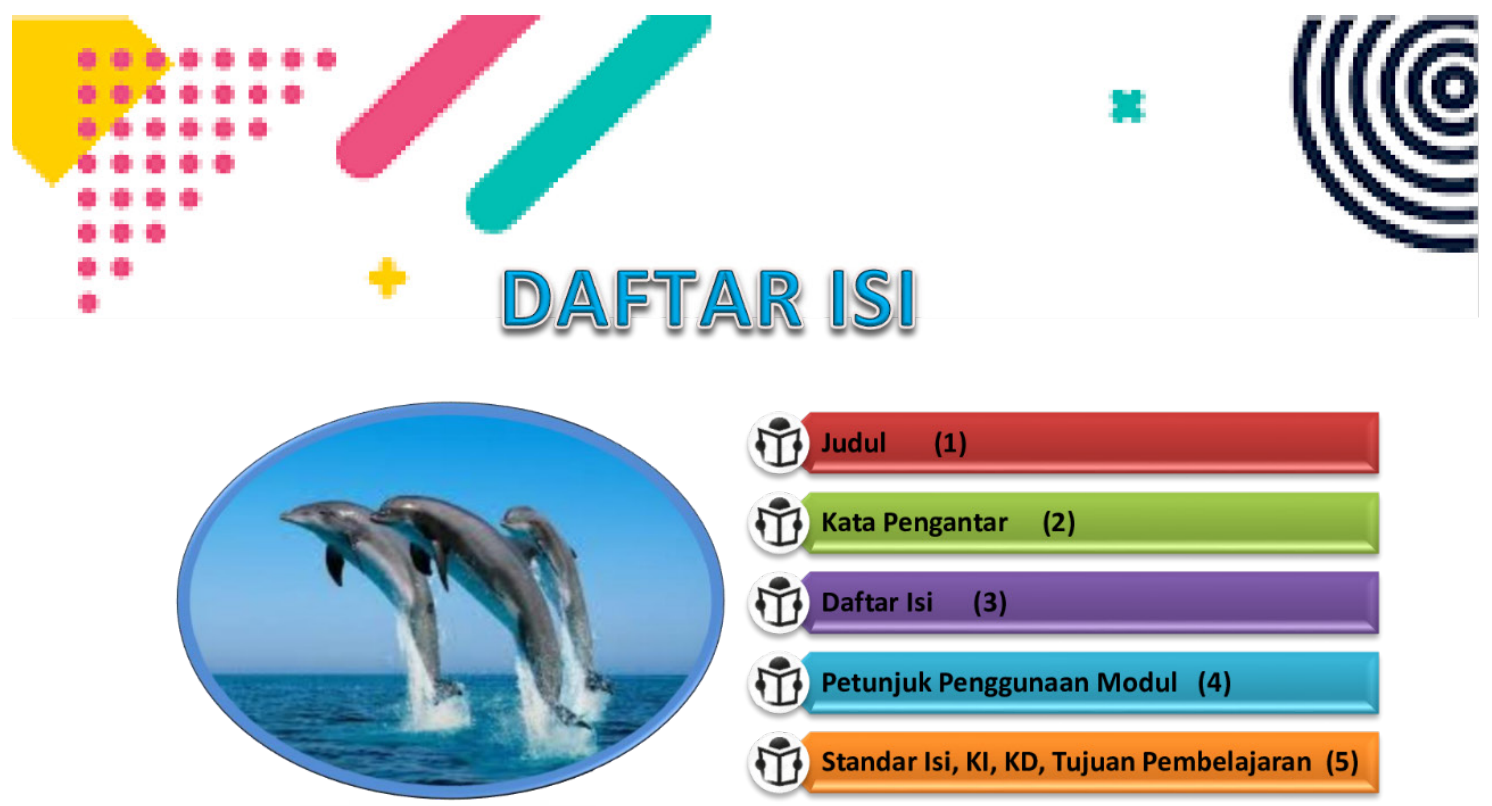

(1]) Judul (1)

1i? Kata Pengantar (2)

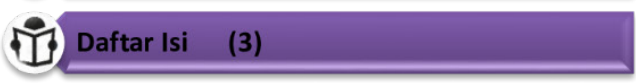

(1). Petunjuk Penggunaan Modul (4)

(1]) Standar ISi, KI, KD, Tujuan Pembelajaran (5)
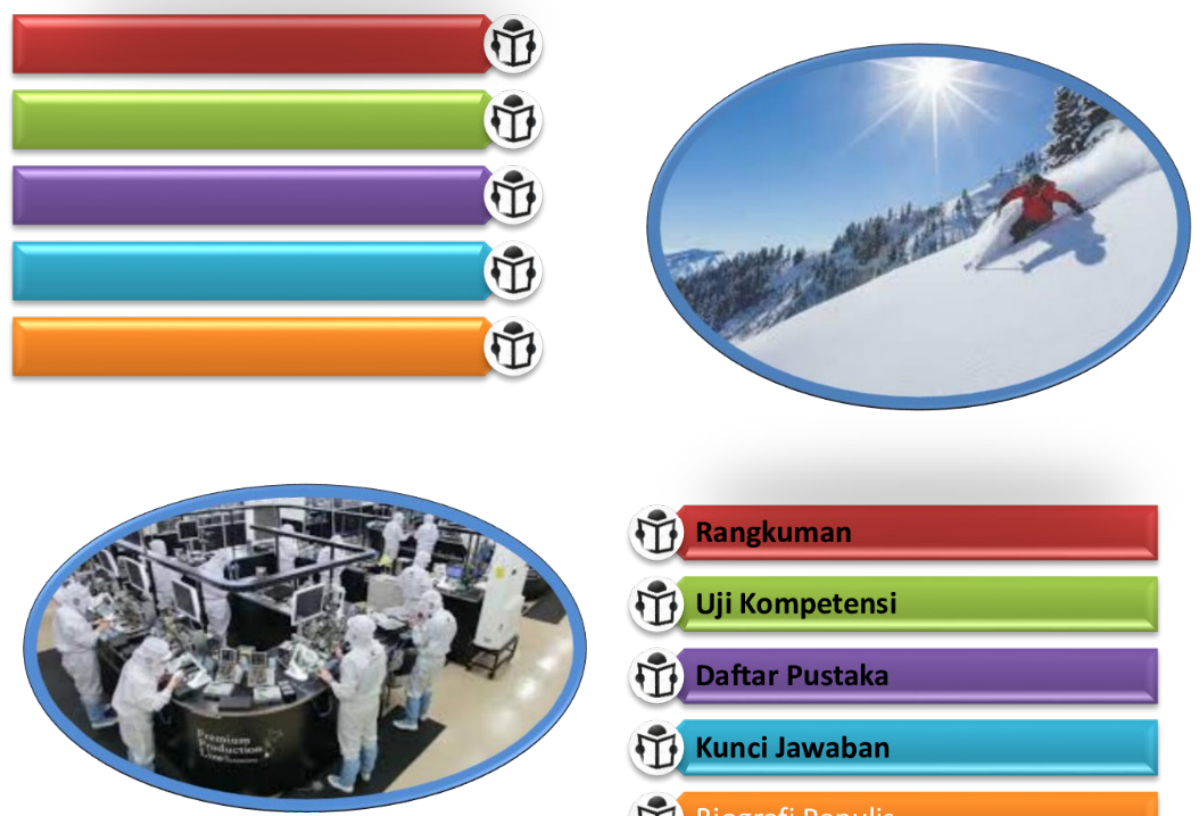

(1). Uji Kompetensi

(1.) Daftar Pustaka

(15) Kunci Jawaban

(1). Biografi Penulis

$$
\text { 去 }
$$
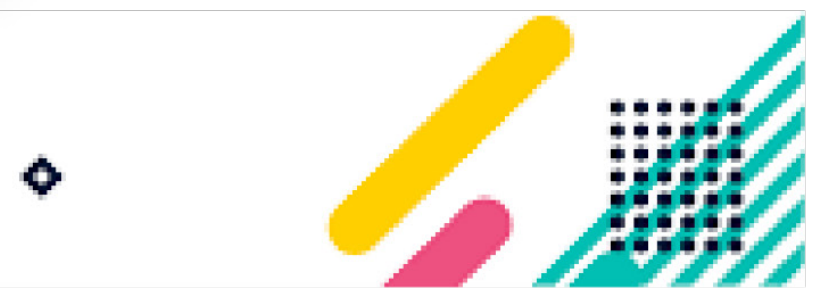

Figure 5. Table of Contents 
Table of contents is the main page that will be viewed to find out the content contained in the Module, and then the table of contents is made interesting so that after opening the table of contents it can attract the interest of readers and students to open the contents in it.

\subsubsection{Module Usage Instructions}

A module that has a unique character that is applying the problem-based learning model and the material contained therein aims to stimulate critical thinking skills. The author adds instructions for using the module as in Figure 6 so students can more easily understand the module.
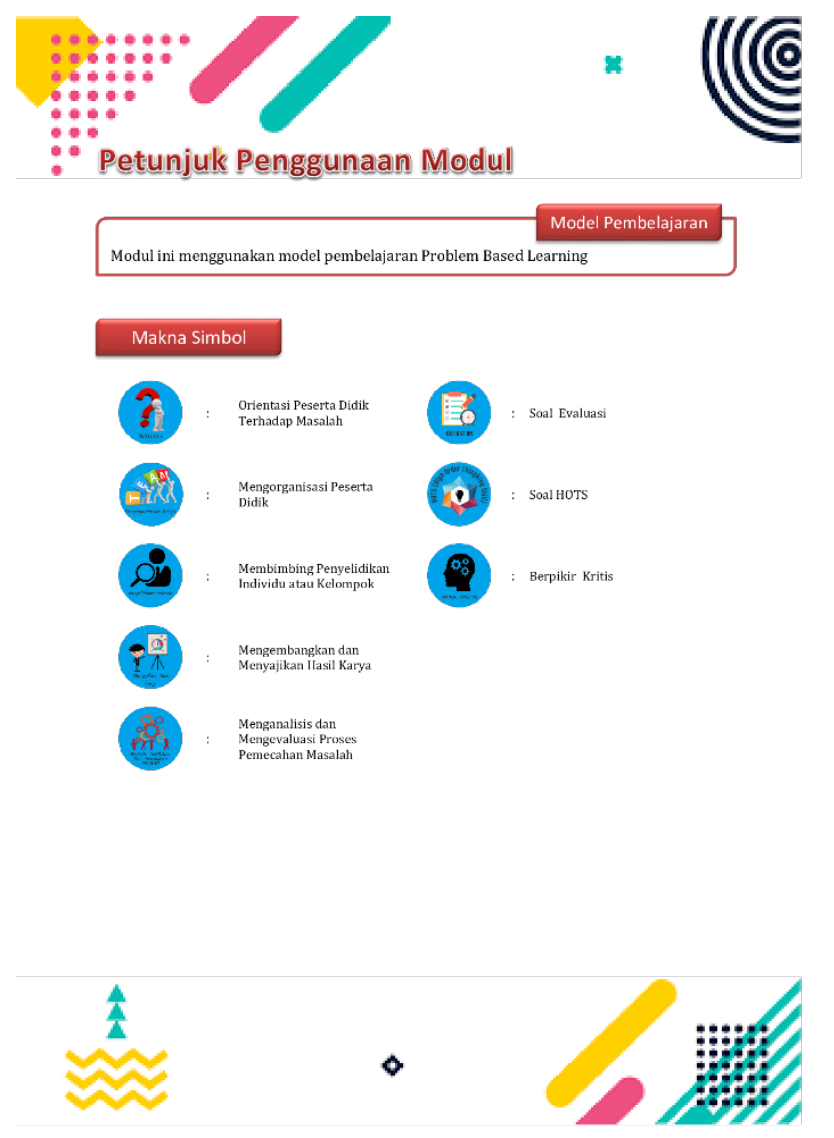

Figure 6. Instructions for Using the Module

Instructions for Using the Module in Figure 6 are the learning models used, namely the PBL model and the meaning of symbols used in the module. PBL stage symbols, namely student orientation towards problems, Organizing Students, Guiding Individual or Group Investigations, Developing and Presenting Work,
Analyzing and Evaluating Problem Solving Processes. Other symbols are symbols of critical thinking, judgment, and HOTS.

\subsubsection{Basic Competency and Competency Achievement Indicators}

Basic competencies and indicators of achievement of competencies from this module are shown in Figure 7.
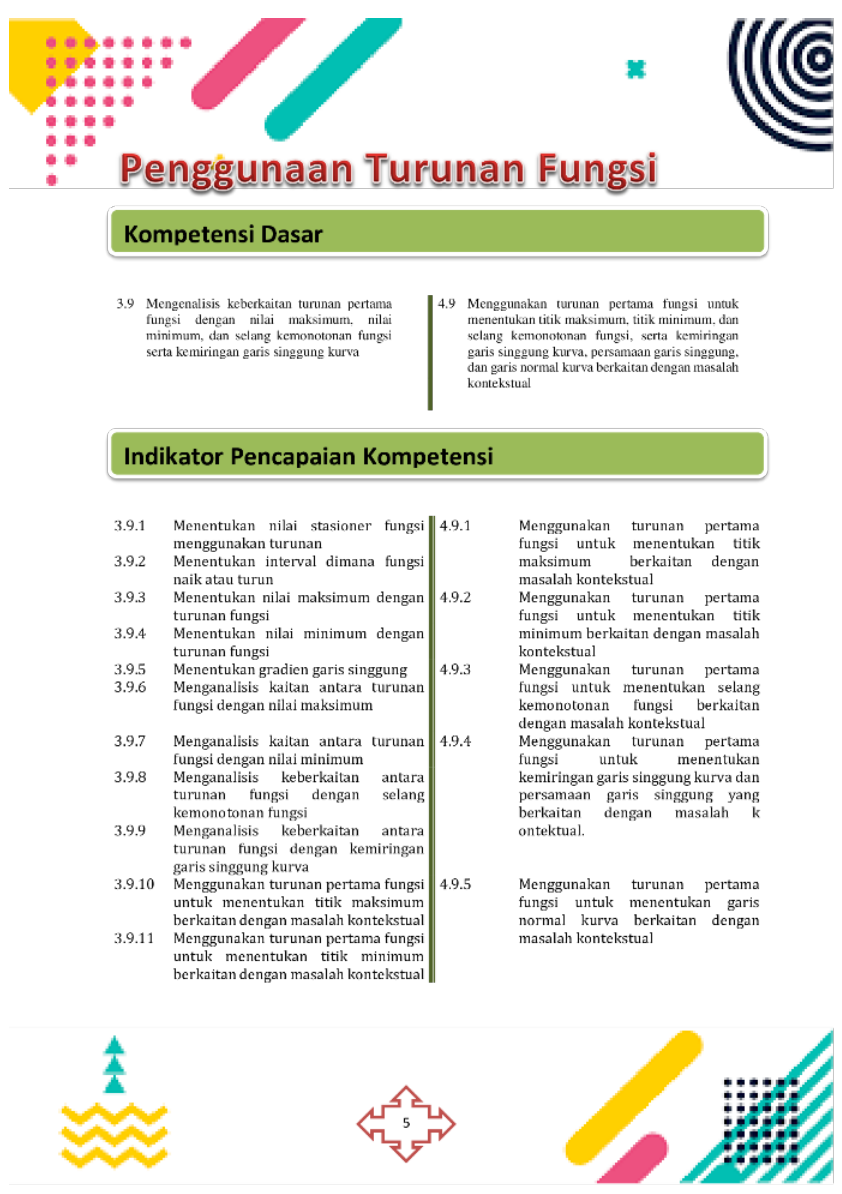

Figure 7. Basic Competencies and Competency Achievement Indicators

The basic competencies written in the module are in accordance with Table 1. In addition to the basic competencies in figure 7, the Competency Achievement Indicators are also contained described in Table 2. 
Table 2. Competency Achievement Indicators

\begin{tabular}{|c|c|c|c|}
\hline \multicolumn{2}{|c|}{ Knowledge } & \multicolumn{2}{|l|}{ Skills } \\
\hline 3.9 .1 & $\begin{array}{l}\text { Determining the stationary value of a function using } \\
\text { derivatives }\end{array}$ & 4.9 .1 & $\begin{array}{l}\text { Using the first derivative of a function to determine the maximum } \\
\text { point related to contextual issues }\end{array}$ \\
\hline 3.9 .2 & $\begin{array}{l}\text { Determining the interval at which the function goes } \\
\text { up or down }\end{array}$ & 4.9 .2 & $\begin{array}{l}\text { Using the first derivative of a function to determine the minimum } \\
\text { point associated with a contextual problem }\end{array}$ \\
\hline 3.9 .3 & $\begin{array}{l}\text { Determining the maximum value with function } \\
\text { derivatives }\end{array}$ & 4.9 .3 & $\begin{array}{l}\text { Using the first derivative of a function to determine the interval of } \\
\text { a function related to contextual problems }\end{array}$ \\
\hline 3.9 .4 & $\begin{array}{l}\text { Determining the minimum value with function } \\
\text { derivatives }\end{array}$ & 4.9 .4 & $\begin{array}{l}\text { Using the first derivative of the function to determine the slope of } \\
\text { the tangent curve and the tangent equation related to the } \\
\text { intellectual problem }\end{array}$ \\
\hline 3.9 .5 & Determining the tangent gradient & 4.9 .5 & $\begin{array}{l}\text { Using the first derivative of a function to determine the normal } \\
\text { line of a curve related to contextual problems }\end{array}$ \\
\hline 3.9 .6 & $\begin{array}{l}\text { Analyzing the relationship between function } \\
\text { derivatives with maximum values }\end{array}$ & & \\
\hline 3.9 .7 & $\begin{array}{l}\text { Analyzing the relationship between function } \\
\text { derivatives with minimum values }\end{array}$ & & \\
\hline 3.9 .8 & $\begin{array}{l}\text { Analyzing the relationship between function } \\
\text { derivatives and function monotonic intervals }\end{array}$ & & \\
\hline 3.9 .9 & $\begin{array}{l}\text { Analyzing the relationship between the derivative of } \\
\text { the function and the slope of the tangent curve }\end{array}$ & & \\
\hline 3.9 .10 & $\begin{array}{l}\text { Using the first derivative of a function to determine } \\
\text { the maximum point related to contextual issues }\end{array}$ & & \\
\hline 3.9 .11 & $\begin{array}{l}\text { Using the first derivative of a function to determine } \\
\text { the minimum point associated with a contextual } \\
\text { problem }\end{array}$ & & \\
\hline
\end{tabular}

\subsubsection{Concept Maps}

The concept map in this module is used to explain the concept structure. Design of concept map in the module can be seen in Figure 8. 

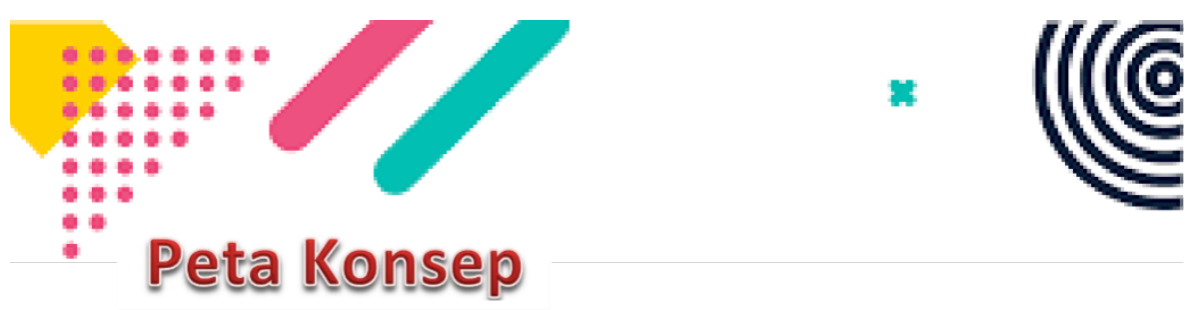

Peta Konsep
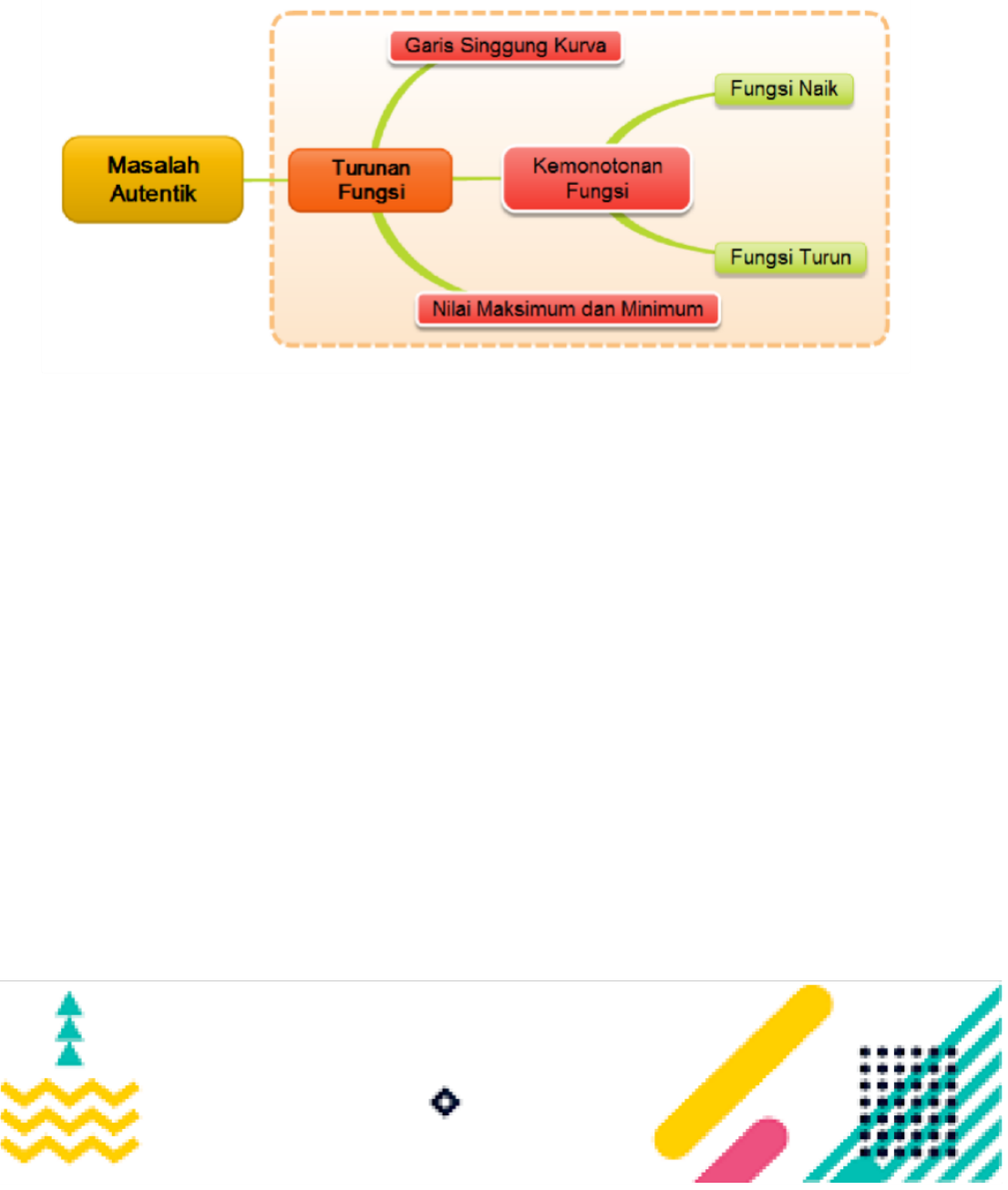

Figure 8. Concept Map Design

The design of the concept map in Figure 8 contains the followings as shown in Figure 9.

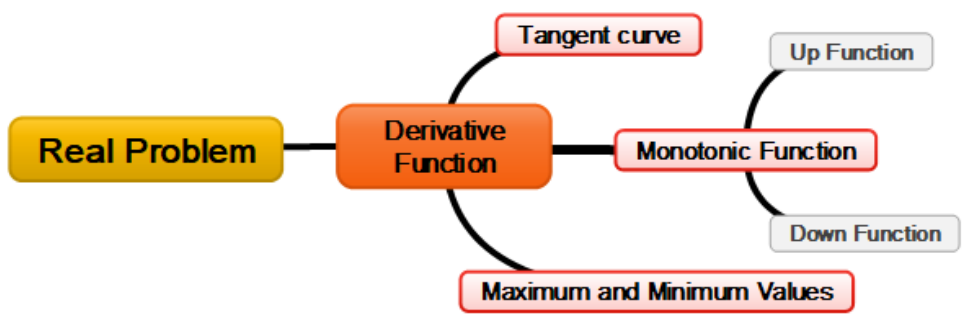

Figure 9. Concept Map 


\subsubsection{Learning Materials}

Table 3. Stages of Problem Based Learning [22]

\begin{tabular}{|l|l|}
\hline No & Learning Stages \\
\hline 1 & Learner orientation to the problem \\
\hline 2 & Organize students to learn \\
\hline 3 & Assist individual and group investigations \\
\hline 4 & Develop and present the work \\
\hline 5 & Analyze and evaluate the problem solving process \\
\hline
\end{tabular}

Learning activities contain learning material, examples of questions, and group discussion material to present the results. The learning activities in this module use the model of problem-based learning, so the steps of learning activities use the stages of problem-based learning as in Table 3

In the first stage, namely the orientation of students to the problem, this module presented a problem related to material of the function derivative as shown in Figure 10.

In Figure 10, there is a video link with the real problem, which is the movement of dolphins. Dolphins jump to the surface of the sea and then dive. The movement of dolphins can be mathematically illustrated in the form of a function graph. In the process of dolphin movement, it is likely to occur when the position of the dolphin reaches the highest jump and the lowest dive, and this leads to learning the maximum and minimum values.
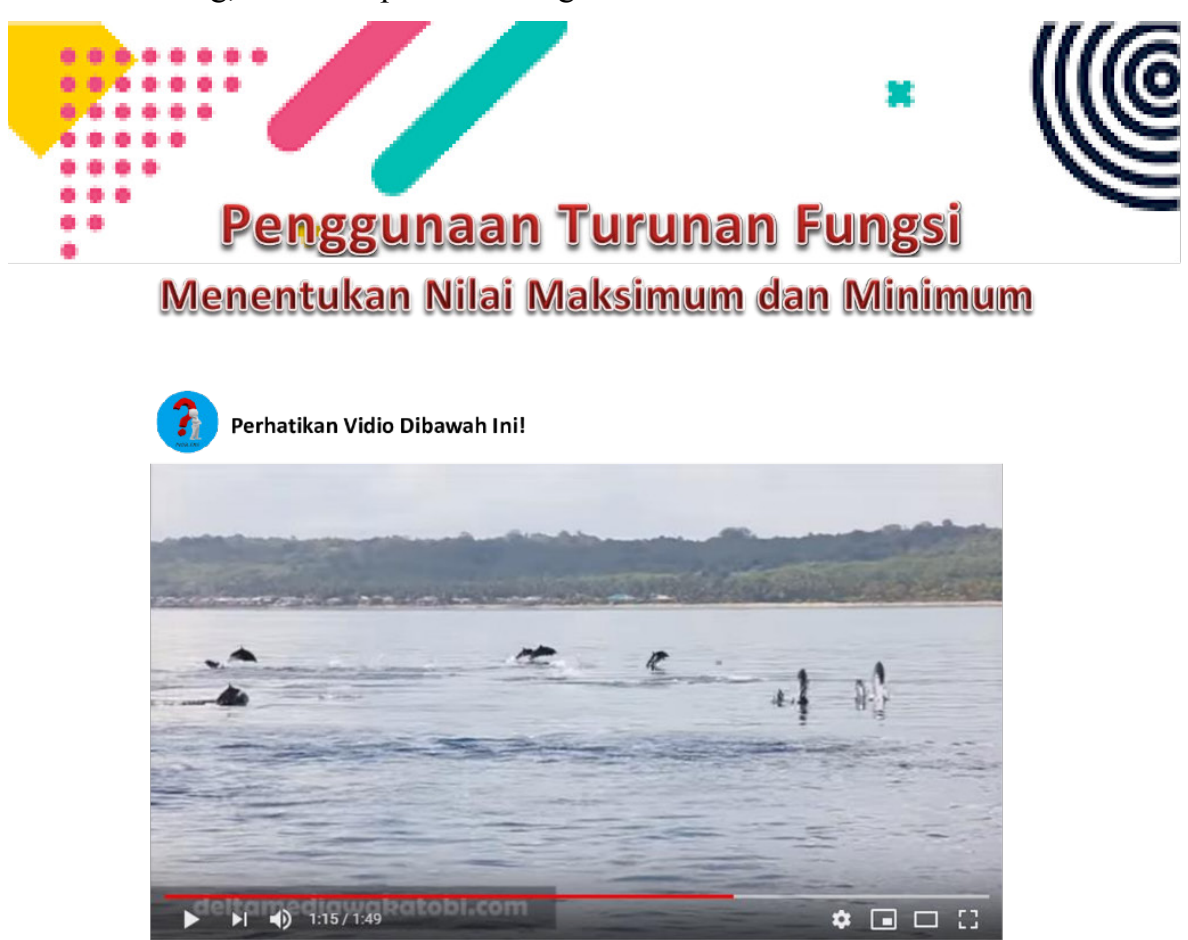

https://www.voutube.com/watch?v=Fl6bk8tBDVM

Dalam gerakan lumba-lumba terlihat lompatan ke atas dan ke bawah. Terlihat bahwa gelombang pergerakan lumba-lumba memiliki puncak maksimum maupun minimum.

Pergerakan lumba-lumba dapat digambarkan dalam grafik fungsi sebagai berikut :
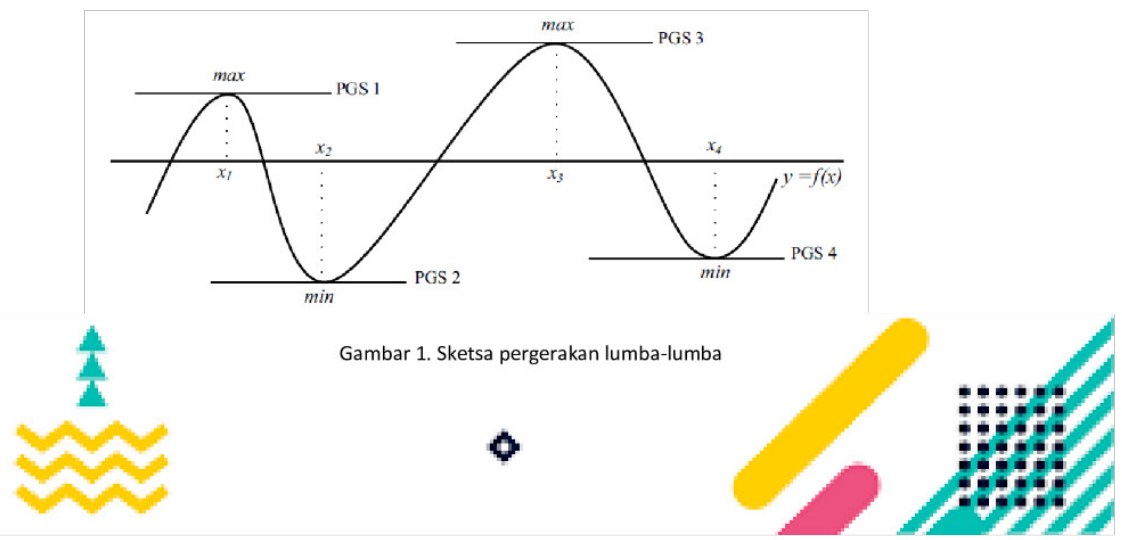

Figure 10. Learning Materials in the orientation phase of students on the problem 
The second stage is organizing students to learn. Designs for organizing students to learn in this module are presented examples of solving the use of derivatives in real problems. Examples of real problems include the one in Figure 11.

The contents in Figure 11 are an example of a real problem: "A box without a lid can be made from a rectangular piece of cardboard with a width of $5 \mathrm{dm}$ and a length of $8 \mathrm{dm}$. This box will be made by cutting the square of the four corners of the carton with side's $x \mathrm{dm}$. What is the size of the box (length, width, height) in order to obtain maximum volume?"

At this stage, examples of real problems are supplemented by alternative solutions. An alternative solution is to start by illustrating the making of the box by the cardboard cut off on four corners as in Figure 12. After the illustrations are formed, students can learn alternative solutions.
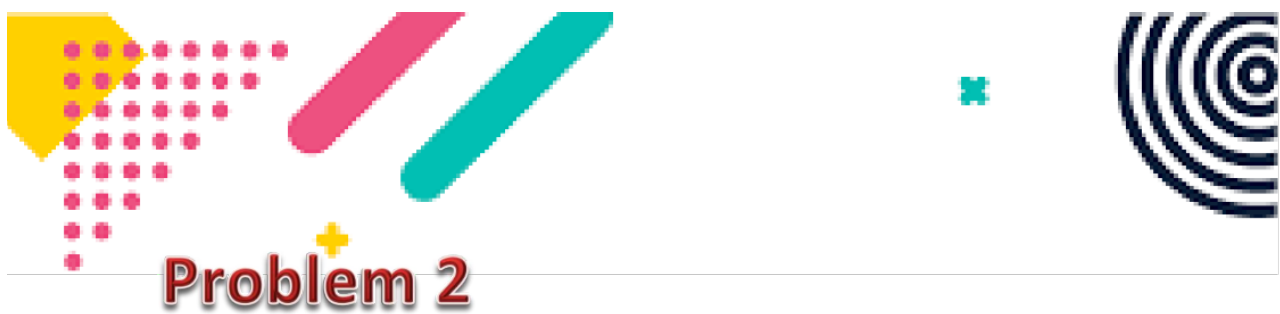

$$
\text { Contoh } 2.1
$$

Selembar karton berbentuk persegi panjang dengan lebar $5 \mathrm{dm}$ dan panjang $8 \mathrm{dm}$ akan dibuat kotak tanpa tutup. Pada keempat pojok karton dipotong persegi dengan sisi $x \mathrm{dm}$. Ukuran kotak tersebut (panjang, lebar, tinggi) agar volume maksimum adalah ....

Alternatif Penyelesaian

Buat ilustrasi gambar

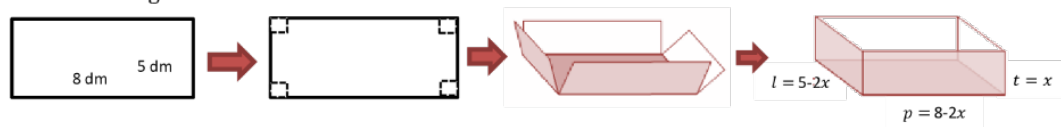

Karena yang akan dicari ukuran balok agar volume maksimum, maka diperlukan persamaan fungsi volume, yaitu

$V=p . l . t \quad$ (dengan mensubtitusikan nilai-nilai panjang, lebar, dan tinggi pada

kotak)

$V=(8-2 x)(5-2 x) x$

$V=\left(40-26 x+4 x^{2}\right) x$

$V=40 x-26 x^{2}+4 x^{3}$

Agar Volume balok maksmum maka $V^{\prime}=0$

$V^{\prime}=0$

$40-52 x+12 x^{2}=0$

$10-13 x+3 x^{2}=0 \quad$ (untuk mempermudah penyelesaian persamaan kuadrat maka persamaan disederhanakan)

$(3 x-10)(x-1)=0 \quad$ (Penyelesaian persamaan kuadrat dengan pemfaktoran)

$3 x-10=0 \quad$ atau $x-1=0$

$3 x=10 \quad$ atau $x=1 \quad$ (penyelesaian untuk $x=\frac{10}{3}$ tidak memenuhi karena lebar karton $5 \mathrm{dm}$ )

$x=\frac{10}{3}$ (tidak memenuhi)

Sehingga nilai $x$ yang memenuhi adalah $x=1$

$p=8-2 x=6 \mathrm{dm}$

$l=5-2 x=3 \mathrm{dm}$

$t=x=1 \mathrm{dm}$

Kesimpulan

Oleh karena itu ukuran kotak agar memiliki volume maksimum adalah $p=6 \mathrm{dm}, 1=$

$3 \mathbf{d m}$ dan $\mathrm{t}=\mathbf{1} \mathrm{dm}$.
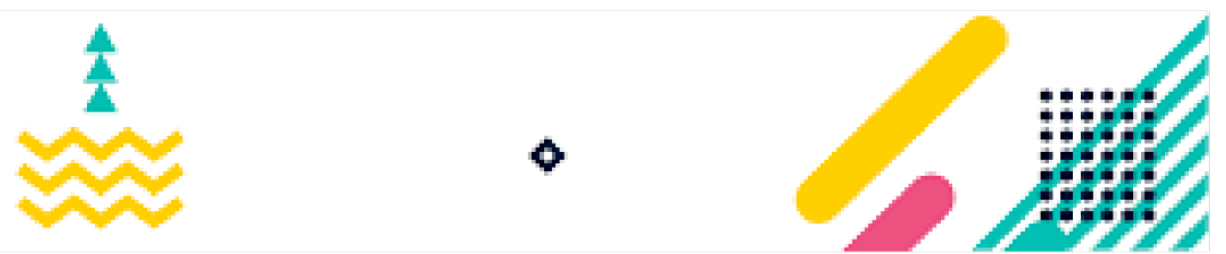

Figure 11. Examples of the use of derivatives in solving contextual problems 


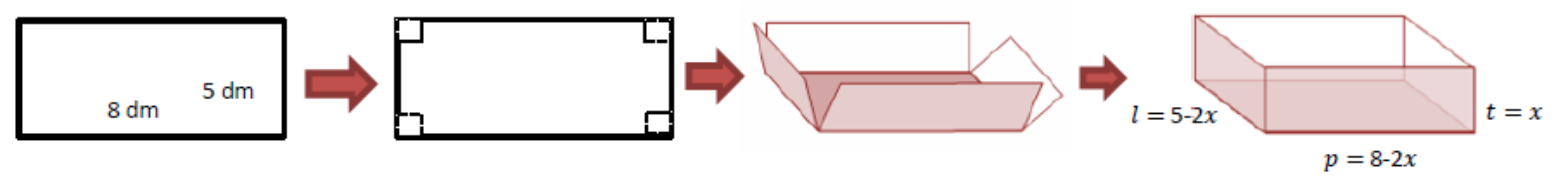

Figure 12. Illustration of the cardboard cut into all four corners

The third stage in problem-based learning is to help with individual or group investigations. The teacher helps students who have difficulty in group discussions. In this Module, given material for group discussion, as shown in Figure 13, which contains "A box without a lid has a square-shaped base. The surface area of the box is $27 \mathrm{~cm} 2$. The volume of the box will be maximum if the length of the base side is ...." and a tub of water without a tubular lid. The total area of the tube without lid is $28 \mathrm{~m} 2$. The volume will be maximum if the base radius is equal to ..." learners discuss with each other to find information to solve the problem given and write the results of the discussion.

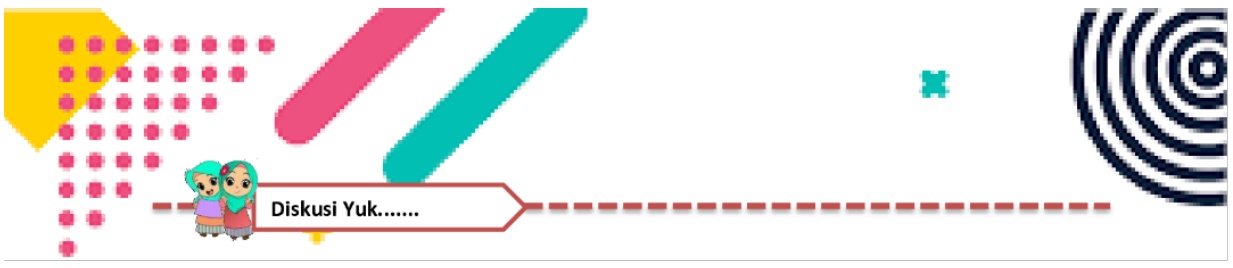

Untuk lebih memahami contoh pada problem 2, diskusikan permasalahan di bawah ini!

Diskusi 2.1

Sebuah kotak tanpa tutup memiliki alas berbentuk persegi. Luas permukaan kotak $27 \mathrm{~cm}^{2}$. Volume kotak akan maksimum jika panjang rusuk alasnya ....

Alternatif Penyelesaian

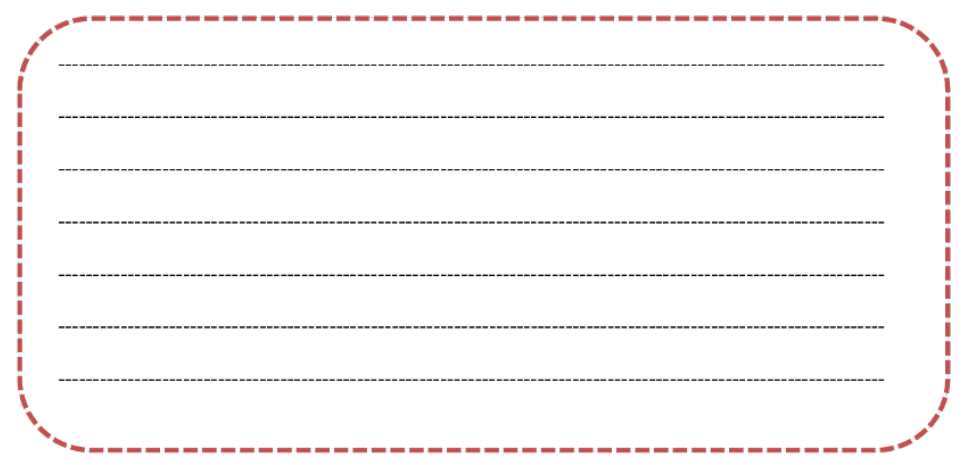

Diskusi 2.2

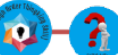

Sebuah bak air tanpa tutup berbentuk tabung. Jumlah luas selimut dan alas bak air adalah $28 \mathrm{~m}^{2}$. Volum akan maksimum, jika jari-jari alas sama dengan ...

Alternatif Penyelesaian

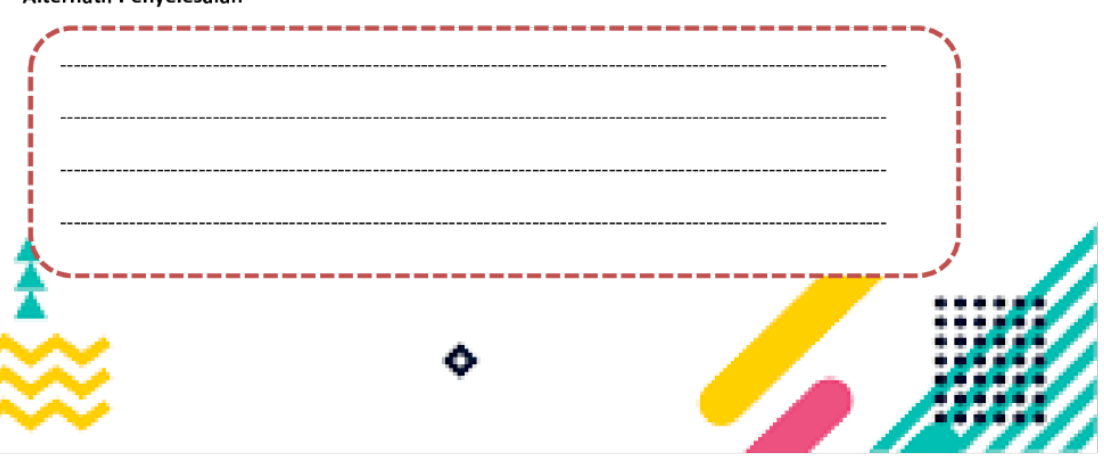

Figure 13. Discussion Sheet 
Based on Figure 13, there is a discussion result sheet filled out by students. Then the results of the discussion will be presented by the group in front of the class. At this stage, participants develop and present their work as the fourth stage of the problem-based learning stage. The fifth stage, is namely analyzing and evaluating the problem-solving process. This stage is done by analyzing and evaluating the results of the presentation of the results of group work. So students get more meaningful learning.

\subsubsection{Exercises}

The module design has exercise. This exercise aims to determine the level of student understanding of the material. The module design for the exercise can be seen in Figure 14.
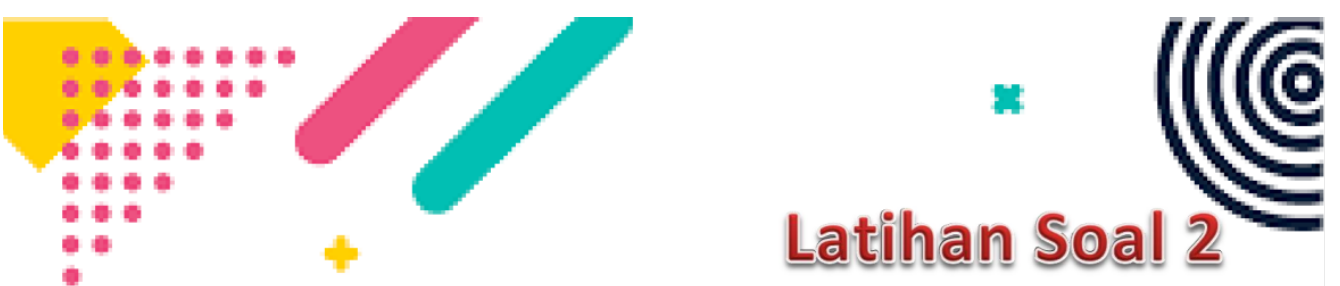

1. Pak Rudi ingin membuat kandang berbentuk persegi panjang seluas $324 \mathrm{~m}^{2}$ untuk ayam peliharaannya. Kandang tersebut akan dipagari dengan kawat berduri seharga Rp. 12.000 per meter. Agar biaya yang diperlukan minimum, berapakah ukuran kandang yang harus dibuat!

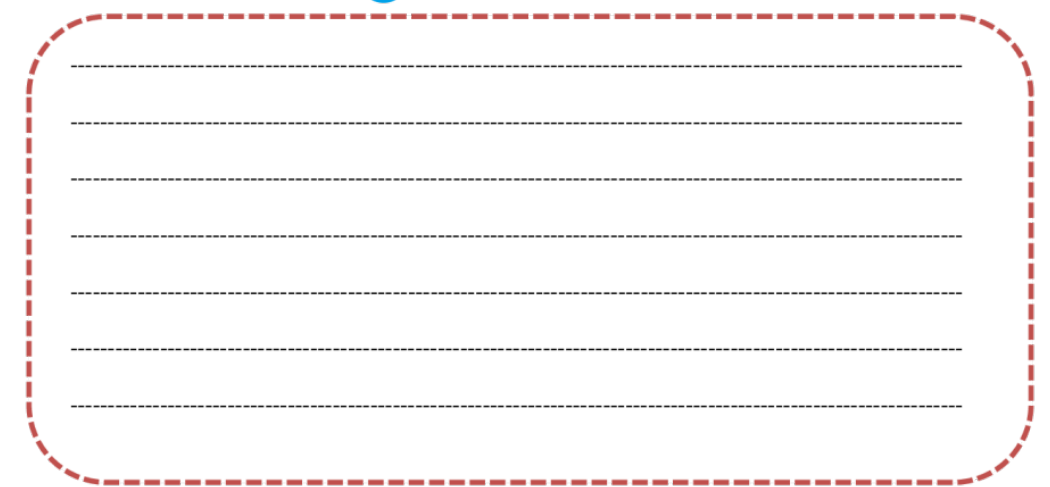

2. Sebidang tanah akan dibatasi oleh pagar dengan menggunakan kawat berduri seperti pada gambar. Batas tanah yang dibatasi pagar adalah yang tidak bertembok. Kawat yang tersedia 800 meter, berapakah luas maksimum yang dapat dibatasi oleh pagar yang tersedia?
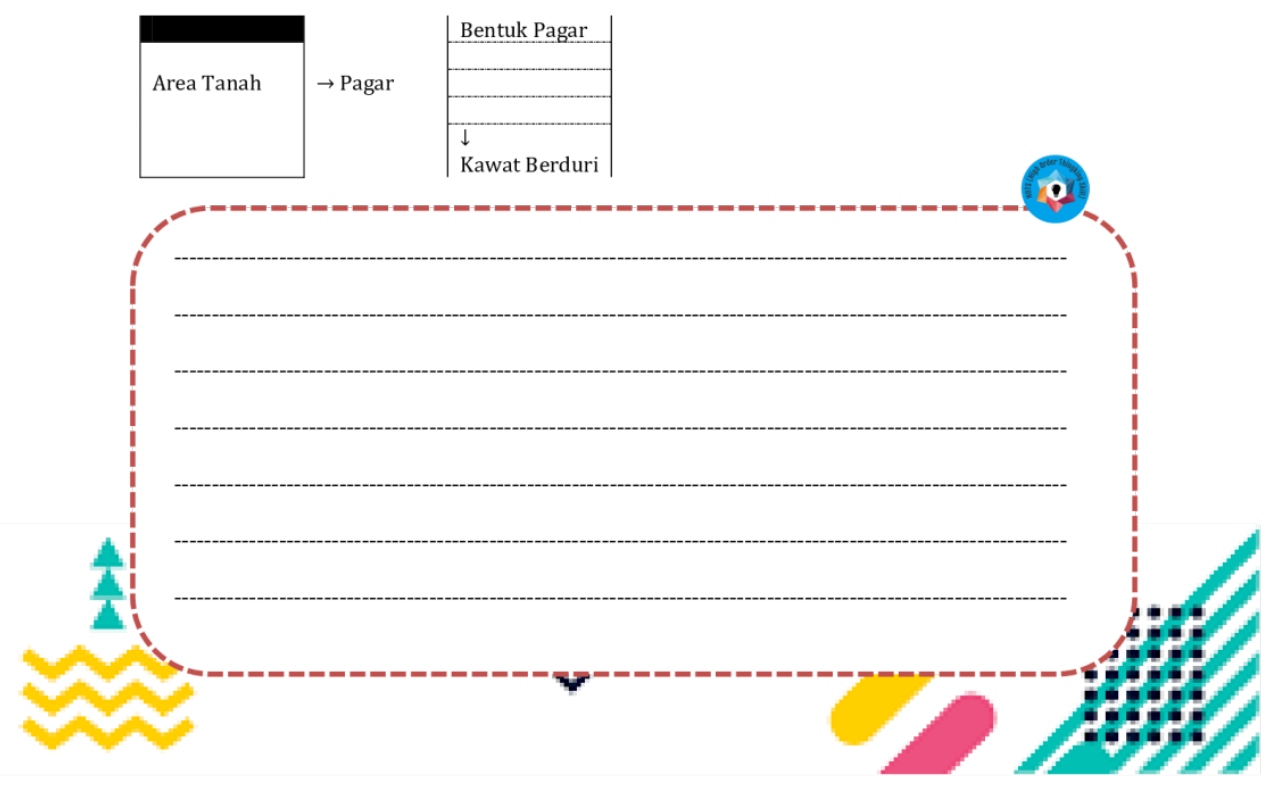

Figure 14. Exercise 
The exercises in Figure 14 are (1). Pak Rudi wants to make a $324 \mathrm{~m} 2$ rectangular cage for his domestic chickens. The cage will be fenced in with barbed wire for $\mathrm{Rp}$. 12,000 per meter. In order to keep costs to a minimum, what is the size of the cage that needs to be made? (2). A plot of land will be limited by a fence using barbed wire. The boundary of land bounded by the fence is not walled. The available wire is 800 meters, what is the maximum area that can be limited by the fence? In Figure 14, there is a HOTS icon on the exercises. This indicates that the question is a category of HOTS.

The design developed is a module that can stimulate students' critical thinking skills, so that the example questions of exercises are made based on contextual problems and require analysis to complete the problems. This exercise HOTS can be trained students to critical thinking.

After the module design is made, validation is carried out by the media expert. The validator is several mathematics teachers who are experts in their fields. Module design validation uses instrument validation in the form of questions. Media expert validators were Amalia Muthia Sayekti, a mathematics teacher at SMK Muhammadiyah 2 Yogyakarta, and Faridatul Oktaviana, a mathematics teacher at Muhammadiyah Sewon Middle School.

Module designs are assessed or validated by media experts. The following are categories of ideal design assessment criteria, as in Table 4.

Based on the results of the assessment of media experts for Module Design, the results shown in Table 5 are obtained.

Based on Table 5 it can be seen that the validation score shows that the design of the module developed is categorized very good so that it is feasible to use.

Table 4. Categories of criteria for the ideal assessment design

\begin{tabular}{|c|c|c|}
\hline Range of Scores & Calculation & Category \\
\hline $\bar{x}>\mathrm{Mi}+1.8 \mathrm{SBi}$ & $\bar{x}>88.2$ & Very good \\
\hline $\mathrm{Mi}+0.6 \mathrm{SBi}<\bar{x} \leq \mathrm{Mi}+1.8 \mathrm{SBi}$ & $71.4<\bar{x} \leq 88.2$ & Good \\
\hline $\mathrm{Mi}-0.6 \mathrm{SBi}<\bar{x} \leq \mathrm{Mi}+0.6 \mathrm{SBi}$ & $54.6<\bar{x} \leq 71.4$ & Pretty good \\
\hline $\mathrm{Mi}-1.8 \mathrm{SBi}<\bar{x} \leq \mathrm{Mi}-0.6 \mathrm{SBi}$ & $37.8<\bar{x} \leq 54.6$ & Not good \\
\hline $\bar{x} \leq \mathrm{Mi}-1.8 \mathrm{SBi}$ & $\bar{x} \leq 37.8$ & Very Poor \\
\hline
\end{tabular}

Table 5. Results of Module Validation Assessment

\begin{tabular}{|c|c|c|c|c|}
\hline No & Name & Position & Score & Criteria \\
\hline 1 & Amalia Muthia Sayekti & Mathematics teacher at SMK Muhammadiyah 2 Yogyakarta & 100 & Very good \\
\hline 2 & Faridatul Oktaviana & Mathematics teacher at Muhammadiyah Sewon Middle School & 95 & Very good \\
\hline
\end{tabular}




\subsection{The Relationship between PBL, Module Design, and Critical Thinking Skills}

The learning module design uses the problem-based learning stage to stimulate students' critical thinking skills. The relationship between module design and PBL and critical thinking skills are shown in Figure 15 below:

Stage PBL

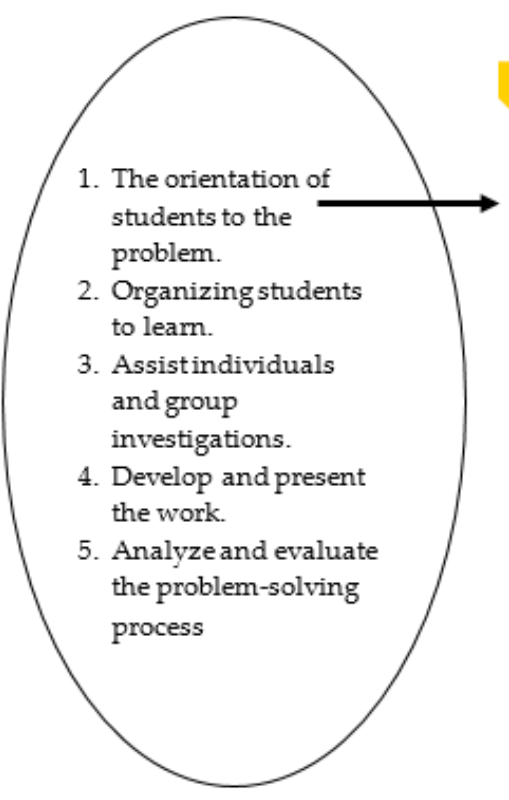

Design Module

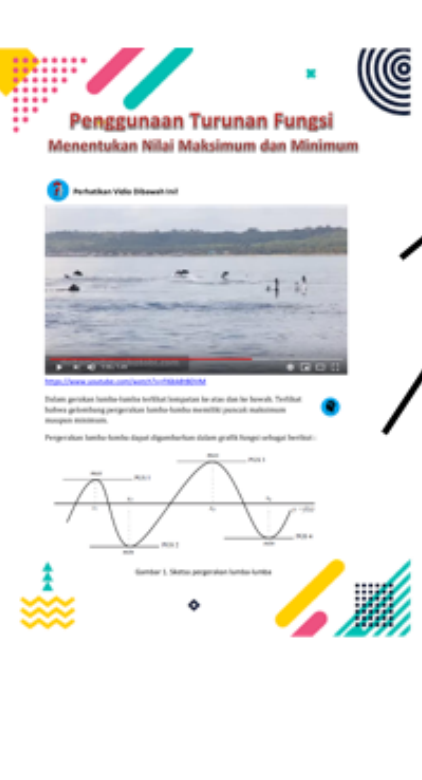

Stage Critical Thinking

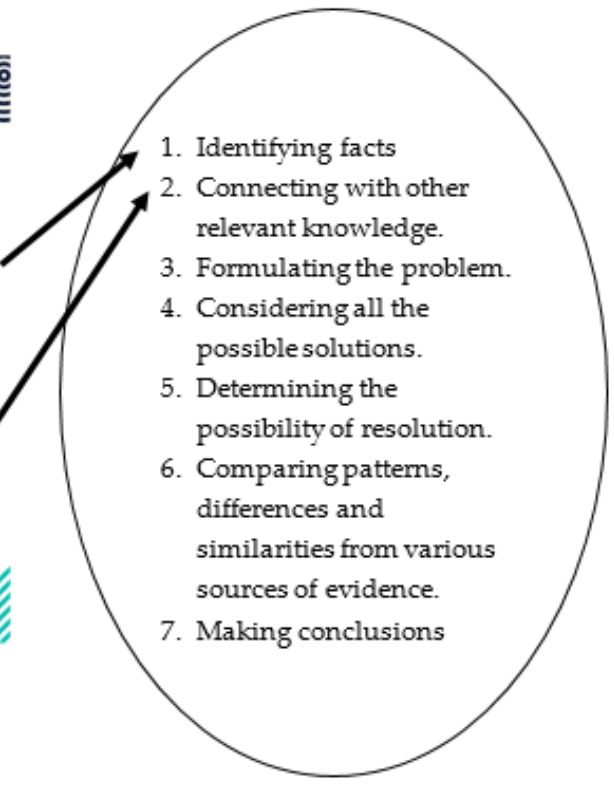

Figure 15a. Relationship between PBL, Module Design, and Critical Thinking Skills 1

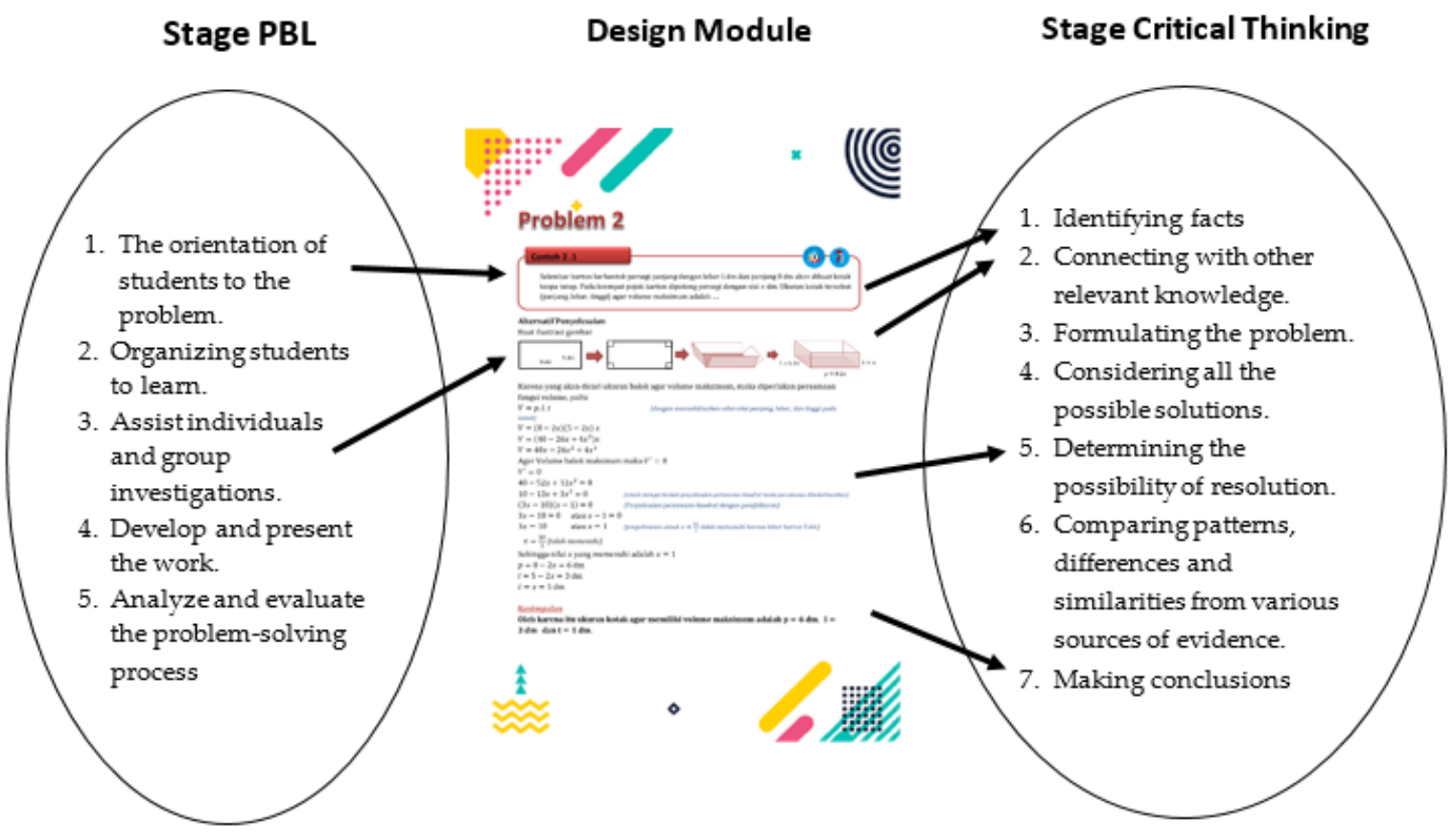

Figure 15b. Relationship between PBL, Module Design, and Critical Thinking Skills 2 
In Figure 15 it is known that the design of learning modules is in accordance with the problem-based learning model and efforts to instill students' critical thinking skills.

\subsection{Advantages of Module}

The advantage of this module is that it can be used as a reference for teaching materials in the process of learning mathematics in high school. This module can help to create interesting learning in the classroom because learning begins with a real problem. Learning uses the problem-based learning stage, developed based on the problem-based learning stage, to improve students' critical thinking skills.

\section{Conclusions}

The results obtained indicate that the PBL-based mathematics learning module design has been carried out at the analysis and design stage. The results of curriculum analysis found that the curriculum used was the 2013 curriculum. Students had difficulty in learning calculus material and needed media that could help students in calculus learning. At the design stage, the researcher designed several sections namely the cover, introduction, module description, list of competency goals, concept maps, table of contents, and learning material based on problem based learning.

The results of the assessment of media experts obtained an average of 97.5 categorized very well so that the module design is feasible to use. The suggestion from researchers is that further research is needed to develop modules based on problem-based learning that can be used in learning in schools.

\section{Acknowledgments}

Researchers would like to thank Master of Mathematics Education at Ahmad Dahlan University for encouraging and facilitating researchers to complete this research. Thank you to Abu Bakar Yogyakarta Integrated Islamic High School as a place of research, mathematics teacher and Abu Bakar Yogyakarta High School students, and validator

\section{REFERENCES}

[1] H. Basri, Purwanto, A. R. As'ari, and Sisworo, "Investigating Critical Thinking Skill of Junior High School in Solving Mathematical Problem," International J. Instr., Vol. 12, No. 3, pp. 745-758, 2019.

[2] M. D. Saputra, "Developing Critical-Thinking Skills
Through the Collaboration of Jigsaw Model with Problem-Based Learning Model," International J. Instr., Vol. 12, No. 1, pp. 1077-1094, 2019

[3] C. L. Scott, "Working Papers Preparing Learners for 21st Century Competencies and Skills Overall Vision of Twenty-First Century Pedagogy Conclusions. Next Steps and Future Issues, Issues the Futures of Learning 3: What Kind of Pedagogies for the 21st Century?, Education Research And Foresight, Vol 3" pp. 1-21, 2015.

[4] R. Widyatiningtyas, Y. S. Kusumah, U. Sumarmo, and J. Sabandar, "The Impact of Problem Based Learning Approach to Senior High School Students' Mathematics Critical Thinking Ability," IndoMS-JME, Vol. 6, No. 2, pp. 30-38, 2015.

[5] N.M. Florea, E. Hurjui, "Critical Thinking in Elementary School Children," Procedia - Social and Behavioral Sciences, Vol 180, pp. 565-572, 2015

[6] L. Yuliati, "Student's Critical Thinking Skills in Authentic Problem Based Learning Student's Critical Thinking Skills in Authentic Problem Based Learning," J. Phys Conf. Ser., Vol 1013, 2018.

[7] Ebiendele Ebosele Peter, "Critical Thinking: Essence for Teaching Mathematics and Mathematics Problem Solving Skills," African J. Math. Comput. Sci. Res., Vol. 5, No. 3, pp. 39-43, 2012

[8] B. Y. K. R. Butcher, M. Larson, and M. Lane, "Using Structured Documentation to Enhance Effective Reasoning and Communication," Sci. scope, pp. 44-53, 2019.

[9] P. Turiman, T. S. M. Tengku Wook, and K. Osman, "21st Century Skills Mastery Amongst Science Foundation Programme Students," Int. J. Adv. Sci. Eng. Inf. Technol., Vol. 9, No. 1, p. 46, 2019.

[10] F. N. Sari, Zetriuslita, and A. Wahyuni, "Salo, Application of Problem Based Learning Models to Improve Critical Thinking Skills Mathematically in Science Two Tenth Grade Class Students of Senior High School 1," Math. Res. Educ. J., Vol. 2, No. 01, 2018

[11] M. Maulidiya and E. Nurlaelah, "The Effect of Problem Based Learning on Critical Thinking Ability in Mathematics Education.," J. Phys; Conf. Ser., Vol 1167, 2019.

[12] N. R. Aini, "Problem-Based Learning for Critical Thinking Skills in Mathematics," J.Phys Ser. Conf., Vol 1155, 2019.

[13] M. N. Indriani and S. Mariani, "The Implementation of PBL ( Problem Based Learning ) Model Assisted by Monopoly Game Media in Improving Critical Thinking Ability and Self Confidence," Journal of Primary Education, Vol. 8, No. 3, pp. 200-208, 2019

[14] N. Cotton, "Using an Interdisciplinary Approach with Problem Based Learning for Gifted Learners," 2019.

[15] S. S. Ali, "Problem Based Learning: A Student-Centered Approach," English Language Teaching, Vol. 12, No. 5, pp. 73-78, 2019.

[16] E. Benli and M. Sarikaya, "The Investigation of the Effect of Problem Based Learning to the Academic Achievement and the Permanence of Knowledge of Prospective Science Teacher: The Problem of the Boiler Stone," Procedia - Soc. 
Behav. Sci., Vol. 46, pp. 4317-4322, 2012.

[17] B. P. Syafina, "Designing Student Worksheets To Improve Critical Thinking Ability Based On Problem Based Learning," International Journal of Scientific and Technology Research, Vol. 8, No. 10, pp. 1194-1199, 2019.

[18] R. Momo and S.Revelation, "Skill Analysis of Students Creative Thinking in the Implementation of Problem Based Leraning with Plastic Waste Handling Contexts 1 Student of Chemistry Science Education School of Postgraduate Studies," Journal of Physics: IOP Conf. Series, 2008.

[19] V.N. Yulian, "Developing Teaching Materials Using Comic Media To Enhance Students Mathematical Communication," Journal of Physics: IOP Conf. Series, 2018

[20] M.K. Abadi, H. Pujiastuti, L.D. Asaat, "Development of teaching materials based interactive scientific approach towards the concept of social arithmetic for Junior high school students," Journal of Physics, Vol. 812, 2016.

[21] I. Farida,. I. Helsy,. I. Fitriani,. M. A. Ramdhani. Learning Material of Chemistry in High School Using Multiple Representations, IOP Conference, 2018.

[22] E. L. Battle, "Agile Learning Versus ADDIE: The Choice for Instructional Designers in Online Learning Development in Higher Education," ProQuest no 13899639. 2019.

[23] P. Angraini and Suparman, "Students Worksheet Design On Geometry For Seventh Grade Students With RME Approach," International Journal of Scientific and Technology Research, Vol. 8, No. 10, pp. 1155-1158, 2019

[24] I. Andriani and Suparman, "Design of Module to Increasing Critical Thinking Ability for Seventh Grade Students", International Journal of Scientific and Technology Research Vol. 8, Issue 12, pp. 853-856, 2019.

[25] S. Nursolekah and Suparman, "Design of Mathematics Learning Module Based on Problem Based Learning to Improve Critical Thinking Ability Students ", International Journal of Scientific and Technology Research Vol. 8, Issue 12, pp. 2609-2516, 2019.

[26] Steven. J, Instructional Systems Design (ISD): "Using The ADDIE Model," Penn State University: College of Education, 2000. 